\title{
Axel Olrik’in epik yasaları çerçevesinde Zarîfînin Mihr ü Mâh mesnevisi
}

\section{Hulusi EREN1}

APA: Eren, H. (2019). Axel Olrik’in epik yasaları çerçevesinde Zarîfînin Mihr ü Mâh mesnevisi. RumeliDE Dil ve Edebiyat Araşturmaları Dergisi, (16), 364-273. DOI: 10.2900o/rumelide.618958

\section{$\ddot{O} \mathbf{z}$}

Destan türünden sonra ortaya çıkan ve ilk örneklerini XV. yüzyıldan itibaren görmeye başladığımız halk hikâyeleri, halk anlatılarının en yaygını olarak modern roman ve hikâyeye geçişte önemli rol oynamıştır. Anonim olan ve manzum-mensur karışık olarak yazılan halk hikâyeleri ile Klasik edebiyattaki mesneviler arasında muhteva bakımından benzerlikler vardır. Mesnevi nazım şekliyle kaleme alınmış eserlerin birçoğunun çift kahramanlı aşk hikâyesi anlattığı bilinmektedir. Bu mesnevilerden biri de Mihr ü Mâh'tır. XVII. yüzyıl şairlerinden Çorlulu Zarîfínnin hamse sahibi olmak amacıyla Nizâmîyyi örnek alarak yazdığı eser, Mihr ile Mâh arasında geçen aşk hikâyesini anlatmaktadır. Tarihî-Coğrafi Fin Kuramı'nın önemli temsilcilerinden biri olan Axel Olrik, halk anlatıları içerisinde bulunan belli temel yapıların varlı̆̆ından söz ederek anlatıcının bilerek ya da bilmeden bunları takip ettiğini ifade eder. Bu çalışmada söz konusu mesnevi farklı bir açıdan ele alınarak Danimarkalı halkbilimci Axel Olrik’in halk anlatılarından yola çıkarak oluşturduğu on beş maddelik "epik kanunları teorisi” bağlamında incelenmiştir. Çalışmanın sonunda Mihr ü Mâh mesnevisinin Olrik’in epik kurallarından birçoğunu içerdiği görülmüş, bu bağlamda sözlü kültür ile Klasik edebiyattaki mesnevi geleneğinin birbirinden kopuk olmadığı kanısına varılmıştır.

Anahtar kelimeler: Halk hikâyesi, mesnevi, Axel Olrik’in epik yasaları, Zarîfî, Mihr ü Mâh.

\section{The mesnevi of Zarîfî within the framework of Olrik's epic laws}

\begin{abstract}
Folk stories which emerged after the epic genre and whose first examples began to be seen from the 15th century, played an important role in the transition to modern novels and stories as the most common of folk narratives. There are similarities in terms of content between folk stories which are anonymous and written as verse-prose mixed and mesnevi in Classical literature. It is known that many of the works written in mesnevi verse tell a double hero love story. One of these mesnevi is Mihr ü Mâh. The work of Çorlulu Zarîfî, one of the 17th century poets, taking Nizâmî as an example in order to have a hamse, tells the story of love between Mihr and Mâh. In this study, this mesnevi is examined from a different perspective and examined in the context of the epic laws theory of fifteen items which was created by the Danish folklorist Axel Olrik based on folk narratives. At the end of the study, it was seen that Mihr ü Mâh mesnevi included many of Olrik's epic rules. In this context, it is concluded that oral culture and mesnevi tradition in Classical literature are not disconnected from each other.
\end{abstract}

Keywords: Folk tale, Mesnevi, Axel Olrik’s epic rules, Zarîfî, Mihr ü Mâh.

1 Dr. Öğr. Üyesi, Muş Alparslan Üniversitesi, Fen Edebiyat Fakültesi,Türk Dili ve Edebiyatı Bölümü (Muss, Türkiye), hulusieren@gmail.com, ORCID ID: 


\section{Giriș}

Sözlük manası "gerçekte olmuş veya tasarlanmış olayların belirli bir kalıp içinde yazılı yada sözlü olarak anlatılması" (Çağbayır 2007: 1963) şeklinde olan hikâye, Arapçadaki "taklid etmek” anlamının karşılı̆̆ı olan öykünmeden türetilmiştir. Olağanüstü olayları konu edinen destan türüyle benzer yönlerinin bulunması nedeniyle en eski ifade türlerinden biri olarak kabul edilir. Dünya edebiyatında ilk edebî örneklerin mitolojik eserler olduğu kabul edilmekle beraber pek çok millette edebiyatın destanlarla başladığı bilinir. Destanlardan sonra teşekkül eden halk hikâyeleri manzum-mensur karışık olmakla birlikte mensur kısmının ağırlıklı olması, tarihî bir olaya dayanması, kişi ve olayların gerçeğe daha uygun olması, kahramanlıktan ziyade aşk maceralarına yer vermesi bakımından destanlardan ayrılır (Türkmen 1998: 488).

Halk hikâyeleri XV. yüzyıldan sonra destanın yerini alır. Destanlardan halk hikâyeciliğine geçiş dönemi eseri sayılan Dede Korkut Hikâyeleri bu türün en eski örneği sayllır. Destanlardaki dışa dönük mücadele halk hikâyelerinde topluma yönelmiş, içtimai konuların daha sık işlenmesiyle beraber bu hikâyelerdeki "alp tipi” yerini "âşık tipi”ne bırakmıştır. Destan söyleyen ozanın yerini de halk hikâyesi söyleyen âşı almıştır. İlk zamanlarda Leyla ile Mecnun, Yusuf ile Züleyha ve Ferhad ile Şirin gibi Arap ve İran edebiyatlarının klasik konularını âşı tarzı halk hikâyeleri formatında işleyen ve anlatan âşıklar; daha sonraları halk arasında yaşanmış, destanlara ve türkülere konu olmuş eski ve yeni aşk ve kahramanlık olaylarını da halk hikâyesi tarzında düzenleyerek anlatmışlardır (Arslan 2008: 260).

Göçebe yaşam tarzından yerleşik hayata geçişin ilk ürünleri olarak aşk ve kahramanlık konularını işleyen bu hikâyeler çoğunlukla Hint-İran, Türk ve Arap-İslam kaynağından gelir. Masal ve destan gibi özel anlatıcıları olan halk hikâyelerinin, âşık ve meddahlar gibi özel anlatıcıları vardır. Çoğunlukla âşığın sevgiliyi elde etme yolundaki gönül maceralarını anlatan bu hikâyeler, asırlar boyu insanların gönül dünyasının tercümanı olmuştur. Nazım-nesir karışımı bir anlatımla yazılan halk hikâyeleri, kalıplaşmış ifadelerden de sıkça faydalanır. Yazmalarda nisbeten daha ağır olan dil, sözlü varyantlarda daha sade ve açıktır. Hikâyelere konu olan olaylar gerçek ya da gerçeğe yakındır. Âşıkların etrafında teşekkül eden hikâyeler genelde mutlu sonla bitmez. Çoğunlukla âşılların bir araya gelmeden öldükleri görülür (Bars 2014: 307).

Halk hikâyelerine bakıldığında, destan geleneğinden pek çok özelliğin tevarüs ettiği görülür. Anlatıcının sazlı olması, ses ve mimik taklitlerinin varlı̆̆ı, dinleyici-anlatıcı ilişkilerinin benzerliği, anlatıcının çıraklık döneminden sonra ustalaşması, anlatının uzun olması gibi hususiyetler destan geleneğinin halk hikâyesi üzerindeki tesirlerindendir (Boratav 1999: 51-52). Türk hikâyeciliği Klasik edebiyatın başladığı devre kadar Anadolu'da genellikle halk hikâyesi biçiminde devam etmiştir. Klasik edebiyatın teşekkülü ve İran edebiyatından mesnevi nazım şeklinin benimsenmesi manzum hikâyenin gelişmesinde önemli rol oynamış, mensur hikâyecilik basit görülerek hikâyeler daha çok mesnevi nazım şekliyle telif edilmiştir. Ancak her ne kadar aruz vezniyle yazılmış olsalar da geniş halk kitlesine hitap etme amacıyla sade bir halk diliyle söylenmiş olmaları, halk hikâyesi geleneğinin etkisini sürdürdüğünü gösterir (Kavruk ve Pala, 1998: 491).

\section{Axel Olrik'in Epik Yasaları}

İskandinavya'da farklı amaçlarla başlamış olmasına rağmen halkbilimi faaliyetleri uzun bir geçmişe sahiptir. Bu yönüyle Coğrafî Fin Okulunun tarihçesinin İskandinav ülkelerinin geçmişiyle yakın ilişkisi vardır. Malzeme derleme işi İsveç kralı Gustavus Adolphus'un 1632 yılında papazlardan folklor 
malzemeleri toplamalarını istemesiyle başlamış, 1830'larda Herder ve Grimm kardeşlerin çalışmalarının tesiriyle istikrara kavuşmuştur. Finlandiya'da XVI. yüzyılda reformcu din adamları, Fincenin yaşaması için ilk halkbilimi çalışmalarını başlatırlar. Din adamları bazı dinî eserleri Finceye tercüme ederler. Fin Kilisesi de kültürel bağımsızlıklarını korumak amacıyla derleme çalışmalarını başlatır. Abraham Poppius ve Anders Sjorgen adlı iki üniversite öğrencisi tarafından 1814 yllında başlatılan derleme çalışmaları, Elias Lönnrot ile zirveye ulaşır. Lönnrot 1835 yılında uzun yıllar süren çalışmaları sonucunda "Kalevala" adlı epik destanı yayınlar. Finliler bu destanla bağımsız bir kültür ve tarihe sahip olduklarını anlar. Julius Krohn'un kurucusu olarak kabul edildiği Tarihî-Coğrafi Fin Yöntemi, Finli halkbilimcilerin çalışmaları sonucunda ortaya çıkar (Çobanoğlu, 2002: 111-114).

\begin{abstract}
“Tarihî-Coğrafi yöntem temeli itibariyle sözlü halk anlatmalarının, özellikle de masalların veya bir masalın nerede ve ne zaman yaratıldığını ve onun muhtemel ilk şeklinin ne olduğunu belirlemeyi amaçlar. Yönteme göre, her anlatı belli bir zamanda, belli bir yerde yaratılmıştır. Illk şekli, yöntem mensuplarının verdiği adla ifade etmek gerekirse 'Ur-form'u belli bir yerde ve zamanda yaratılan bir halk anlatması, tıpkı suya atılan taşın oluşturduğu dalga benzeri bir şekilde, ticaret ve göç gibi etkenler altında yayılmaya başlar. Sözlü yayılma yanında, yazılı ve basılı metinler de bu yayılmanın genişlemesine yol açacaktır” (Ekici, 2006: 90).
\end{abstract}

Tarihî-Coğrafi yöntemin mensuplarına göre her halk anlatmasının pek çok eş metni bulunabilir. Halkbilimi araştırmacısının görevi bir anlatının eş metinlerini toplamak, bunlardan birini asıl metin olarak kabul etmek, tüm metinler arasında karşlaş̧tırma yaparak anlatmanın ilk şeklini kurmaktır. Böylece bir metnin yayılma yolları ve ilk defa nerede yaratıldığı belirlenecek, anlatının yaşam öyküsü ortaya çlkacaktır.

Axel Olrik'in Epik Yasaları, Tarihî-Coğrafi Fin yönteminin genişlemesini, anlatıların yapılarının çözümlenmesini sağlayan ilk örnektir. A. Olrik Epik Yasaları'nda, her halk anlatısının içinde belli yapıların bulunduğunu öne sürer. A. Olrik'in bu yasaları, zaman zaman eleştirilmiş olmasına rağmen, kendisinden sonraki halkbilim çalışmalarına ve yeni kuramların oluşmasına büyük katkılar sağlamıştır. Axel Olrik, toplumsal hafızada saklanan kültürel verilerin "sage"lerde (halk masalı, mit, efsane, halk şarkısı vb.) bilinçli veya bilinçsiz bir şekilde korunduğunu göstermek için halk anlatılarının epik kurallarını on beş maddede toplamış ve bu tespitlerini birçok eser üzerinde ispatlamaya çalışmıştır. A. Olrik'in halk anlatılarının epik kuralları araştırmacılar tarafından farklı anlatı türlerine uygulanmıştır. ${ }^{2}$

\title{
Çorlulu Zarîfî ve Mihr ü Mâh mesnevisi
}

Doğum ve ölüm tarihleri net olarak bilinmeyen Zarîfi’nin Râhatül-Ervâh adlı eserinde geçen bir beyte göre Çorlulu olduğu anlaşılmaktadır. Katip Çelebi, onun Behiştînnin öğrencisi olduğunu söyler. Eserlerini Sultan I. Ahmed'e ithafen yazması Zarîfînin XVII. yüzyll şairlerinden biri olduğu kanaatini doğurmaktadır. Mürettep bir Dîvân sahibi olması, Râhatü'l-Ervâh adlı mensur eserini Sâdî̀nin Gülistân'ına nazire olarak yazması ve Mihr ü Mâh mesnevisini Nizâmî̀yi örnek alarak hamse sahibi olma amacıyla kaleme alması onun sıradan bir şair olmadığını gösterir. Eserlerinden devrinin iyi yetişmiş bir şairi ve nasiri olduğu anlaşılmaktadır (Turhan, 1995: 6-7).

Çift kahramanlı bir aşk hikâyesi olan Mihr ü Mâh, 1217 beyitten müteşekkildir. Klasik mesnevi tarzında tertip edilen eser tevhid, münacat, na't ve sebeb-i telif ile başlayıp esas hikâyenin anlatıldığı manzumelerle devam etmektedir. Eserin metni Vedat Nuri Turhan'ın“Zarîfinin Mihr ü Mâh

\footnotetext{
2 Bu konuda yapılan çalışmalar için bkz. Özcan 1996, Yılmaz 1999, Adıgüzel 1999, Zariç 2007, Gülmen 2008, Yılmaz 2009, Erdoğan 2010, Akyüz 2012, Çiftçi 2013, Tuncel 2013, Bars 2014. 
Mesnevisinin Tenkitli Metni ve İncelemesi” isimli yüksek lisans tezinden (1995: 76-193) alınmıştır. Söz konusu çalışmaya göre mesnevinin olay örgüsü özet olarak şöyledir:

Halkı tarafından çok sevilen adil, güçlü-kuvvetli ve yiğit bir pehlivan olan Hilâl isimli Müslüman bir şah yaptığı fetihlerle ülkesinin sınırlarını genişletmektedir. Hilâl Şâh Çin’in de büyük kısmını fethetmiş, havasını beğendiği için kendisine buraları payitaht edinmiştir. Bu hükümdarın Mâh adında güzellikte eşsiz bir oğlu olur. Hükümdar oğlunun emrine gözüpek ve maharetli yüz genç verir. Mâh bu gençlerler birlikte zaman zaman gezer, eğlenir ve ava gider. Ancak kendine çok güvenen Mâh, bazen bu yardımcılarını terk eder ve yalnız olarak ava ve gezintiye çıkar. Bu durum babası Hilâl Şâh'ın kulağına gider ve onu endişelendirir.

Hilâl Şâh, bir gün maiyetiyle beraber mecliste iken huzuruna bir elçi gelir. Hoten hanının selamını iletir ve onun zor durumda olduğunu, yardımına ihtiyaç duyduğunu bildirir. Bunu işiten Hilâl Şâh, hemen ordusuna toplanması için emreder. Kuvvetlerini topladıktan sonra Hilâl Şâh, oğlu Mâh'ı huzuruna çağırır ve ona üç değerli nasihatta bulunur. Bunlardan ilki, kendisi gidince yerine hükümdarlık etmesidir. Ancak istediği halka daima iyi davranan, kötülüğe karşılık bile iyilikle mukabele eden bir hükümdarlıktır. İkincisi, adaletten kesinlikle ayrılmaması ve herkese eşit davranmasıdır. Sonuncu nasihat ise av ve gezintiye yalnız çıkmaması, arkadaş ve yardımcılarını asla terk etmemesidir.

Babası Hoten hanına yardım için sefere çıkar çıkmaz tahta geçen Mâh, gece gündüz çalışıp babasını aratmaz. Halk tarafından çok sevilir ve "âdil şâh" olarak anılır. Bir gün kırda arkadaşlarıyla sohbet ederken arkadaşlarından bir tanesinin ani ölümü Mâh’ı çok etkiler ve teessüründen ağlamaya başlar. Gaipten gelen bir ses Mâh’a üzülmemesini, ömrün geçici olduğunu ve dünya nimetlerinden elini çekmesini söyler. Bunun üzerine hemen tövbe eden Mâh, Mağrib Sarayı'na giderek abdest alıp mescide girer. Namaz kılar, dua ile Allah'tan af diler. O esnada uykuya dalar. Rüyasında Hz. Peygamberi görür. Mâh'a günahlarının affedildiği ve bir av vesilesiyle Mihr adında bir güzelle karşılaşıp onunla sevgili olacağı müjdelenir. Mâh kendine gelince hemen ava çlkmaya karar verir. Babasının da nasihatini hatırlayarak yanına yüz adam alır ve seher vakti yola çıkar.

Av esnasında Mâh’ın önünden aniden bir ceylan geçer. Atını onun ardından sürer ve bu esnada kendisini korumak üzere görevlendirilen arkadaşlarından uzaklaşır. Uzun bir kovalamacadan sonra avını yakalar ancak vakit geç olduğu için geceyi çimenlik bir sahrada uyuyarak geçirir. Uykudan uyandığında etrafında gördüğü askerleri kendi askerleri sanan Mâh, yanıldığını anlar. Pervîn adlı gayrımüslim bir hükümdarın askerleri tarafından yakalanıp esir alınarak Pervîn'in köşküne götürülür. Pervîn, başında tac ile üzerinde Rüstemâne kıyafeti olan Mâh’ı görünce onun sıradan biri olmadığını anlar ve ona kim olduğunu sorar. Mâh, Çin şahı olduğunu söyleyince Pervîn askerleriyle Mâh'ın üzerine yürür. Mâh da kılıcını çekerek savaşır. Ancak atının sendeleyip düşmesiyle yakalanır. Pervîn, Mâh’ın öldürülmesini emreder. Ancak cellatlar, "babası Hilâl Şâh oğlunun öldürüldüğünü duyarsa bizi de sağ bırakmaz" derler. Bunun üzerine Pervîn vezirini çağırır ve ona danışır. Vezir de bir ziyafette Mâh’ın misafir gibi ağırlanmasını, ona sihir yapılarak dininden dönmesi için şerbet yerine şarab içirilmesini söyler. Yine de İslamiyet’i terk etmezse Pervîn Şâh’a güzel kızını süsleyip Mâh’ın karşısına çıarmasını önerir. Böylece Mâh’ın kızına aşık olup dininden döneceğini ve Pervîn’in ordusunun başına geçerek kendi babasına karşı savaşacağını söyler.

Pervîn, vezirinin bu öğüdünü çok beğenir ve aynen uygular. Ancak mecliste kendisine sunulanın şarap olduğunu anlayan Mâh, onu içmeyi reddeder. Buna bozulan Pervîn, kızının getirilmesini ister. Mâh, rüyasında gördüğü kızı karşısında bulunca ondan çok etkilenir. Pervîn, kızının adının Mihr olduğunu ve ancak İslamiyet’i terk ederse kızı ona vereceğini söyler. Mâh bunu reddeder ve İslâm’ı öven bir gazel 
söyler. Buna hiddetlenen Pervin, Mâh'ın üryan bir hâlde boynuna zincir takılarak zindana atılmasını emreder. Zindanda bulunan diğer mahkumlar, Hz. Yusuf kıssasında olduğu gibi Mâh'a hayran kalır. Mihr'in aşkıyla erimeye başlayan Mâh, İslamiyet’ten çıkmayı dahi düşünür, ancak kulağına gelen bir ses onu yine sabra davet eder. Bu arada, Mihr de Mâh’ın hâline çok üzülmüş ve sarayına kapanmıştır.

Mihr, Mâh’ı kurtarmak için çareler düşündüğü sırada kulağına gaipten bir ses “Mâh’a kavuşmak istersen babanın yanına git. Mâh'a gittiğin zaman da küfürden uzak dur” der. Bunun üzerine Mihr babasına gider. Babası da zindana gitmesini, Mâh'ı zindandan çıarıp kendi sarayına götürmesini ve onu dininden uzaklaştırmasını söyler. Mihr, bu isteğini kabul ederek babasının yanından ayrılır. Mihr, zindanda Mâh ile karşılaşır karşılaşmaz oraya gidiş niyetinin aksine İslâmiyet’i kabul eder ve babasının planını Mâh'a anlatır. Mâh plana uyar gibi yapıp zindandan çıkar ve Mihr ile saraya gider. Kaçmak için gece gündüz firsat beklerler. Nihayet Pervîn'in sarayda olmadığı bir gün ata binerek kaçarlar. Bunu gören hizmetçi Pervîn'e haber verir. Peşlerinden askerleriyle giden Pervîn, Mâh ile Mihr’i Yekrah Dağı'nda yakalar.

Mâh, Pervîn'in askerlerine karşı tek başına savaşacağını söylese de Mihr dinlemez ve öleceklerse de beraber ölmeyi istediğini söyler. Mâh kahramanca savaşırken, Mihr’in atı bir kaza sonucu yere yıkılır ve kendisi de yaralanır. Mâh’ın gayretleri sonucu değiş̧irmeyince Pervîn kızını yakalayıp götürür. Mihr’i bir saraya kapatır. Mihr’in götürüldüğünü gören Mâh da meydanı bırakarak yanındaki bir dağa sığınır ve çaresizliğinin babasına malum olması için Allah'a münacata başlar. Çin şahı Hilâl'e bir Kadir Gecesi rüyasında Hz. Muhammed (sav) görünür ve onu oğlunun durumundan haberdar eder. Hita şehrinde korku ile uykudan uyanan Hilâl, sabah olur olmaz ordusuyla sefere çıkar. Pervîn’in ordusunu dağıtarak oğlu Mâh’ kurtarır. Olup biteni kendisine anlatmasını ister. Hilâl, Mâh'ın başına gelenleri duyunca hışımla Pervin'in üzerine yürür ve memleketi terk etmesini ya da cizye ile kızını teslim etmesini söyker. Pervîn de cizye ile kızını vermeye razı olur. Hilâl Şâh, Mihr ile Mâh’ı alarak Çin'e döner. Onların nikahlarını kıyar. Günleri zevk ve safa ile geçerken bir müddet sonra Hilâl Şâh ölür. Bunun üzerine, Mâh babasının yerine tahta geçerek devlet idaresini ele alır ve adil bir şekilde devletini yönetir. Bir gece Mâh, aniden hastalanır, hastalığı gitgide ilerler. Verilen ilaçlar da tesir etmez ve vefat eder. Mâh'ın ölümü üzerine karalar giyen Mihr, kendi canını da alması için Allah'a yalvarır. Nihayet duası kabul olur ve Mâh'ın arkasından Mihr de ruhunu teslim eder.

Mihr ü Mâh mesnevisinde olay, iki kişi arasında cereyan eden bir aşk hikâyesi olduğu için hikâyenin birinci derecede kahramanlarının Mâh ve Mihr olduğu söylenebilir. Olayın ikinci derecede kahramanları ise Mâh'nn babası Hilâh Şâh ve Mihr’in babası Pervîn Şâh’tır. Olayın cereyan ettiği değişik safhalarda ortaya çıkan diğer kahramanlar üçüncü derecede kahramanlar olup hemen hepsi figüran durumundadırlar. Mâh'ın canciğer yüz arkadaşı, Hıta sultanı Hoten Hân, Pervîn'in veziri, savaşan askerler vs. hepsi bu konumdadırlar. Olayın şahıs ve karakterlerini ${ }^{3}$ şu şekilde bir tablo ile göstermek mümkündür:

\begin{tabular}{|l|l|l|}
\hline & İyi Karakter & Kötü Karakter \\
\hline 1. Derece Kahramanlar & Mihr, Mâh & \\
\hline 2. Derece Kahramanlar & Hilâl Şâh & Pervîn \\
\hline 3. Derece Kahramanlar & $\begin{array}{l}\text { Hoten Hân, yüz asker, zindandaki } \\
\text { insanlar }\end{array}$ & Pervin'in veziri ve askerleri \\
\hline
\end{tabular}

$3 \quad$ Mesnevilerde karakter tasnifi için bkz. Ünver 1986. 


\section{A. Olrik'in Epik Yasaları ve Mihr ü Mâh mesnevisi}

“A. Olrik, halk anlatılarıyla ilgilenen herhangi bir kimsenin uzaktaki bir halkın edebiyatını okuduğu zaman, bu halkın ve onun geleneksel anlatılarının o kimseye şimdiki kadar tamamen yabancı olsa bile, bu anlatılarla daha önce karşılaşmış gibi bir duyguya kapıldığını söyler. Bu tanışıklığı açıklamak için de iki etken ileri sürer:

“1. İlkel insanın ortak zihin özelliği,

2. Bu özelliğe uygun olarak doğa kavramı ve ilkel mitoloji” (Olrik, 1994a: 2).

A. Olrik'in ilkeleri kural olarak da adlandırılmaktadır. Yukarıda özeti verilen Mihr ü Mâh mesnevisini Axel Olrik’in Epik Yasaları ışığında şu şekilde değerlendirmek mümkündür:

\section{Giriş ve bitiş kuralı:}

"Sage4 birdenbire başlamaz ve birdenbire bitmez. Sage durgunluktan coşkunluğa doğru giderek başlar ve çoğu zaman asıl kahramanlardan birinin başına gelen bir felaketi içeren bir sonuç olayından sonra coşkunluktan durgunluğa giderek biter"(Olrik 1994a: 2).

Mesnevi, olayın geçtiği Çin ülkesinde Hilâl Şâh’ın hükümdarlığının anlatılmasıyla başlar.

Hilâl adlu meger var idi bir şâh

Göğe irgürmişidi çetr ü hargâh

Hilâl-i devleti bedr olmuş idi

Cihâna nûr-1 'adli tolmış idi (201-202)5

Nazîri yog idi 'asrında anun

Güzîde pehlivânıydı cihânun (207)

Mesnevinin girişinde yapılan tasvirlerle Hilâl Şâh'ın gücü ve kudreti, devletinin büyüklügü̈, adil yönetimi somutlaştırılmaya çalışılmıştır. Eserin bu bölümündeki monotonluk hemen dikkati çeker. İlerleyen bölümde Mâh'ın olaylara dahil olmasıyla birlikte coşkunluk başlar. Mâh, daha önce rüyasında gördüğü Mihr’i çeşitli vesilelerle gördükten sonra ona hemen âşık olur. Bu andan itibaren hikâye artan bir şekilde coşkunluğa doğru ilerler. Mihr’in de Mâh'a âşı olmasıyla coşkunluk daha da artar. Mihr’in gayrımüslim babası Pervîn’in, İslamiyet’i terk etmeyen Mâh’ı zindana attırması,

Azîz-i Mısr-ı hüsn iken o hânî

Varup habs itdiler Yûsuf-veş anı

Çü habsi ol gazâle itdiler yir

Esed-veş urdılar boynuna zencîr (593-594)

Mihr'in babasına rağmen ve dinini değiştirip Müslüman olarak Mâh'ı kurtarması, bir seher vakti onunla kaçması gibi bölümlerde heyecan hiç azalmadan devam eder. Ancak hikâyenin anlatımında artarak

A. Olrik "sage"yi anlatı kelimesinin yerine kullanmaktadır.

Parantez içindeki rakamlar mesnevinin beyit numaralarını ifade etmektedir. 
süregelen bu coşkunluğun giriş ve bitiş kuralına da uygun olarak anlatının son bölümünde en üst seviyeye ulaştığı görülür. Mâh’ı çaresiz bir şekilde mağarada beklerken dua etmesiyle hâlinin babası Hilâl Şâh'a malum olması ve babasının gelip Mâh’ kurtarmak ve Mihr’i oğluna almak için askerleriyle Pervîn'in üzerine yürümesi hikâyede coşkunluğun zirveye ulaştı̆̆ı anlardır.

Meded kıl kim katı dermânda kaldım

Garîb ü ‘âciz ü hicrânda kaldım

Ki senden dileğim ey Hayy u Kayyûm

Benim hâlim atama eyle ma'lûm (849-850)

Eserin geneline bakıldığında Çin hükümdarı Hilâl Şâh'ın anlatımıyla oldukça durgun bir şekilde başlayan hikâyeye, oluşturulan kurgu çerçevesinde gelişen her olay heyecan katmıştır. Okuyucuda merak uyandıran olaylarla bu heyecan ve coşku anlatının son bölümünde Hilâl Şâh'ın ordusunu Pervîn'in üzerine sürmesiyle tepe yapmış; oğlu Mâh'ı, Pervin'in elinden kurtarıp Mihr'i de alarak hep beraber Çin'e dönmesiyle tekrar durağanlaşmıştır. Bu yönüyle eserin giriş ve bitiş bölümlerindeki kurgunun Axel Olrik’in epik kurallarına uyumlu olduğu görülür.

\section{Yineleme kuralı:}

"Sage yapısının bir diğer önemli ilkesi de yineleme kuralıdır. ... Halk anlatıları tam anlamıyla bu ayrıntıları inme tekniğinden yoksundur ve zaten pek ender olan tasvirle de çok kısa oldukları için konuya önem kazandıran etkili bir araç olamazlar. Geleneksel sözlü anlatımımızda yalnız tek seçenek vardır; yineleme. Bir genç üç gün arka arkaya devler bölgesine gider ve her gün bir dev öldürür. Bir kahraman billur dağa üç kere çıkmak ister. Üç müstakbel aşık bir gece bir kız tarafından büyü ile hareketsiz bırakılır Anlatıda ne zaman çarpıcı bir sahne ortaya çıksa, durum olayın akışını kesmeyecek şekilde uygunsa, sahne yinelenir. Bu sadece gerilimi artırmak için değil, aynı zamanda anlatının boşluklarını doldurmak için de geçerlidir. Yineleme, bazen gerilimi artırıcı, bazen basittir. Ama, önemli olan Sage'nin yineleme olmadan tam olarak kendi biçimini kazanamayacağıdır" (Olrik 1994a: 3).

Mesnevide aynı olaylar birbirine benzer şekilde yinelenir. Yineleme, çoğu halk hikâyesinde olduğu gibi en güzel şekilde rüya motifinde görülür. Mâh rüyasında Mihr’i görerek ona âşı olur.

Saçarken nergisinden güllere âb

Gözin ol lâle-haddin bağladı hvâb (330)

Sana yâr ola bir mihr ü hâdî mihr

Dehânı zerre-i nâçiz adı Mihr (339)

Pervîn Şâh’ın askerleri tarafından kaçırılan ve zor durumda kalan Mâh’ın ahvali babası Hilâl Şâh'a yine rüyasında bildirilir.

Hudâ emriyile ol gice nâgâh

Hilâlün girdi rü’yâsına ol Mâh

Ciger-kûşen senün ya'nî ki ol Mâh

Düşüpdür ceyş-i Pervîn içre nâgâh 
Uyan imdi uyuma aç gözün tur

Seherden kûh-1 yekrehden yana sür (857-859)

Bunun yanında dağa sığınma ve gaipten ses duyma motiflerinin de yinelendiği görülür. Arkadaşının ölümünde üzülen Mâh’a gaipten bir ses üzülmemesini ve tövbe etmesini söyler.

Kılurken 'ayn-ı çeşmin çeşme ol mâh

İrişdi bir nidâ sem'ine nâgâh

Didi pür gussadur gerçi bu kıssa

Velî sanma tehî var bunda hisse (308-309)

Mâh, Mihr'e kavuşma karşılığında sunulan şarabı içmeyi reddedince Pervîn Şâh tarafından yakalanır ve zindana atılır. Orada çektiği eziyetlere dayanamayıp Mihr'e kavuşmak için şahın isteği doğrultusunda dinini değiştirmeyi aklından geçirdiği sırada gaipten bir ses Mâh’a bunu kesinlikle yapmamasını ve sabretmesini söyler.

Bu cevre döymeyüp ol Mâh-ı tâbân

Diledi kim ala Mihri virüp îmân

Hitâb irdi o dem ki ey Mâh sabr it

Bir iki gün dahı cânuna cebr it (612-613)

Mâh’ın hâline çok üzülen ve yaşanan durum karşısında çaresiz kalan Mihr'in nasıl bir yol izleyeceği de yine gaipten gelen bir ses tarafından kendisine söylenir.

Pes oldı dün ü gün efkâra meşgûl

Halâs-ı Mâha bâ’is kâra meşgûl

Bu ra’y üzreyken ol gün yüzli dildâr

İrişdi bir nidâ k'ey mâh-ruhsâr (66o-661)

A. Olrik'in halk anlatılarında bazen gerilimi artırmak bazen de anlatının boşluklarını doldurmak için aynı sahnelerin yinelendiği yönündeki tespiti Zarîfínin Mihr ü Mâh’ı için de geçerlidir. Mesnevide anlatılan hikâyede rüya görme, dağa sığımma ve gaipten ses duyma motiflerinin farklı sahnelerde yinelenmesi Olrik’in “yineleme kuralı”yla uyumludur.

\section{3. Üçler kuralı:}

“... üç sayısı halk geleneklerinin büyük bir bölümünde -eski Yunan, Kelt, Alman- ve ilkelliğin görünüşünü taşıyan masal, ritüel ve efsane gibi bütün türlerde inatla korunmuştur. Üçler kuralı halk gelenekleri dünyasında, yüzlerce ve binlerce yıllık insan kültürü arasından geniş bir orak kesiği gibi uzanmaktadır. ... Gerçek halk anlatılarında veya daha açıkçası, geleneksel olarak üç sayısının etkisi altında olan anlatılar evreninde Üçler Kuralı yıkılmaz egemenliğini sürdürür” (Olrik 1994a: 4).

Mesnevide beş, on, kırk, elli, yüz ve bin sayılarının yanında üç sayısının kullanımına da sıkça rastlanır. Örneğin Hilâl Şâh sefere çıkarken kendisinin yokluğunda ülkeye hükümdarlık edecek olan oğlu Mâh'a aklından hiç çıarmaması gereken üç nasihat söyler. 
Sana lîki kılurven iki üç pend

Ki her birisi makbâl-i hıred-mend (257)

Mâh, Hilâl Şâh ve Mihr'in gördükleri rüya sayısı toplamda yine üçtür. Hilâl Şâh, Mâh'ın zor durumda olduğunun kendisine gaipten bir sesle bildirilmesi üzerine oğlunu kurtarmak için yola koyulur ve hiç durmadan üç gün yol alır. Hilâl Şâh’la Pervîn'in askerleri arasında gerçekleşen savaşın süresi de yine üç gündür.

Bularla iki gün süratle gitdi

Üçünci gün gelüp bir günde yetdi (877)

Büyük bir ordusu ve ülkesi olan Pervîn'in ülkesindeki şehirlerin sayısı üç yüzdür.

Dahı var idi üç yüz şehri mahsûr

Ki her birinün içi taşı ma'mûr (404)

İlk olarak ne zaman ve nasıl kullanıldı̆̆ı, neden hâlâ en sık kullanılan sayı olduğu bilinmemekle beraber mistik ve kozmik birçok olguyu hatırlatan üç sayısı, halk hikâyelerinde önemli bir yer tutmakadır (Akyüz 2012: 5). Mihr ü Mâh mesnevisinde üç sayısının farklı sahnelerde kullanılması Axel Olrik'in "üçler kuralı”yla uyumludur. Bu durum halk hikâyelerinin bir tevarüsü olarak yorumlanabilir.

\section{Bir sahnede iki kuralı:}

"İki, aynı zamanda ortaya çıkan en yüksek kişi sayısıdır. Aynı zamanda ortaya çıkan üç kişiden her birinin kendi kişikleriyle yol alması geleneğin bozulması demektir. Bütün anlatı boyunca sadece iki kişi aynı sahnede ortaya çıkar" (Olrik 1994a: 4).

Mesnevinin başından itibaren gelişen olaylara bakıldığında neredeyse tüm olaylarda iki kişi ön plana çıkmaktadır. Bu durum ise daha ziyade diyalogların olduğu bölümlerde dikkati çekmektedir. Hilâl Şâh'ın oğlu Mâh'a üç nasihat verirken başbaşa kalması,

Hilâle çün mukarrer oldu rıhlet

Çağırdı yanına ol Mâhı halvet (252)

Mâh’ın Mihr’i görüp ona âşık olmasından sonra aralarındaki diyaloglara üçüncü bir kişinin dahil edilmemesi, Pervin’in vezirinden tavsiye almak için yaptığı görüşmede başka kimsenin olmaması,

Dönüp itdi vezîrine hitâbı

Bu derde istedi andan cevâbı (463)

Hilâl Şâh’ın Mihr’i almak için babası Pervîn'in yanına giderken yanına Mâh’ı almayıp yalnız gitmesi ve Pervîn ile ikili görüşmesi eser boyunca, kahramanların olaylarda ikili olarak ön plana çıkarılmasına birer örnek gösterilebilir.

Dün ü gün Mihr ile kasrında halvet

Kılurdı ol kamer-râ 'ayş ü işret (756) 
Girüp zerrîn ü sîmîn câme-hvâbe

Varurdı ikisi bir yerde hvâbe (762)

Anlatılan hikâye boyunca metinde birinci derece karakterler olarak yer alan Mihr ile Mâh'n diyaloglarında üçüncü kimselerin yer almaması, diğer karakterlerin de önem sırasına göre eserde karşıt değer olarak konumlandırılan kişilerle mukabele sahneleri göz önüne alındığında mesnevide "bir sahnede iki kuralı"na uyulduğu söylenebilir.

\section{Zitlık kuralı:}

"Sage'de her zaman kutuplaşma vardır. Kuvvetli bir Thor’un karşısında mutlaka akıllı bir Odin veya kurnaz Loki bulunmaktadır. Hüzünlü bir kadının yanında neşeli ve ferahlatıcı biri oturacaktır. Bu temel zıtlık, epik yapısının önemli bir kuralıdır: Genç ve ihtiyar, büyük ve küçük, insan ve canavar, iyi ve kötü. Zttlık kuralı, Sage’nin baş kahramanlarından, özellikleriyle ve eylemleri baş kahramana zit olma gereksinimiyle belirlenen diğer bireylere kadar etkili olur" (Olrik 1994a: 4-5).

Mihr ü Mâh mesnevisinde iki zıt kutup yer almaktadır. Bu ztt kutuplar iyi ile kötünün, hak ile batılın savaşı şeklinde Hilâl Şâh ve Pervîn üzerinden işlenmiştir. Öte yandan hikâyenin iki baş kahramanı Pervîn kızı Mihr ile Hilâl Şâh'ın oğlu Mâh, birbirlerine âşık olmaları, anlatı boyunca kimseye zarar vermeden aşkları için her türlü fedakarlığı yapmaları ile iyi olan tarafta yer alırlar. Yüz yiğit adam her zaman Mâh'ın yanında olup onun savaş arkadaşlarıdır. Mâh'ın babası olan Hilâl Şâh da adaletli bir hükümdar olarak yine iyinin temsilcisidir. Buna karşın, eserde kötü olanlar da vadır. Mihr’in babası Pervîn ve onun veziri zıtlık kuralında kötü olanı temsil eder. Pervîn, Mihr ile kavuşmalarını engellemek için Mâh’ı zindana attırır. Ona bu fikri veren de veziridir. Hikâyede hak ile batılın da bir mücadelesi görülür. Gayrımüslim olan Pervîn, kızıyla evlenmesine karşılık Mâh’a İslamiyet’i terk etmesini şart koşar.

Dönüp Mâha didi ey şâh-ı hûbân

Senün olsun bu hüsn iline sultân

Şu şart ile içüp mey ey güzel hân

Bunun mihri içün terk eyle îmân (562-563)

Pervîn’in bu teklifini kabul etmememesi üzerine Mâh zindana atılır. Çaresiz kalıp dinini değiştirmek istediği bir anda gaipten bir ses ona sabretmesini söyler. Yaşanan bu durum hak olanın batıl karşısında galibiyeti için Mâh’a yardımı olarak yorumlanabilir.

Hezârân âferîn ol Mâha tahsîn

Visâlüm çün benim terk etmeyüp dîn

Olup Yûsuf gibi mahbûs-ı zindân

Zelîha gibi kıldı beni giryân

Diyüp itdikçe dilden âh ü vâhı

Göğe boyardı çarhı derdi âhı (640-643)

Mesnevide zıtlık iyi ve kötü ile hak ve batıl ekseninde işlenmiş, hikâye hemen her bölümde bu zıt değerlerin çatışması üzerine inşa edilmiştir. Bu bağlamda Hilâl Şâh, Mihr ve Mâh 'iyi’ olanı, Pervîn ve 
yanındakiler ise 'kötü' olanı temsil eden sahnelerde konumlandırılmıştır. Dolayısıyla eserde Olrik’in “zitlık kuralı"yla bir uyum söz konusudur.

\section{6. İlk ve son durumun önemi kuralı:}

"Bir sürü kişi veya nesne peş peşe ortaya çıkınca en önemli kişi öne çıkar. Buna rağmen sonuncu gelen kişi anlatının duygudaşlık doğurduğu kişidir. Bu ilişkiyi denizcilik terimleriyle ifade edebiliriz; 'Baş Tarafin Ağırlığı' (das Toppwicht) ve 'Kıç Tarafin Ağırlığı' (das Achterwicht). Anlatının ağırlığı her zaman Achterwicht'te yatmaktadır. En küçük kardeşin son atılımının masalın içinde ne kadar anlam taşıdığını hepiniz biliyorsunuz. Üçler kuralıyla birleşen Achterwicht halk anlatılarının en önemli özelliğidir, epik bir kuraldır" (Olrik 1994b: 4).

Anlatının olay örgüsüne bakıldığında gelişen diğer olayların hikâyenin merkezinde bulunan iki olay yani ilk ve son olayın etrafında şekillendiği görülür. Başkarakterlerden biri olan Mâh hikâyenin başında olaylara hemen girmez. Hilâl Şâh'ın ülkesinin tasviri ve hükümdarlı̆̆ının sıfatlarıyla başlayan hikâyede Mâh'ın olaylara dahil olması, babası Hilâl Şâh'ın dostu Hoten Hân'a yardım için savaşa çıkmasıyla başlar.

Selâm idüp sana ey şâh-ı devrân

Hıtâ sultânı yaini kim Hoten Hân (243)

Hilâle çün mukarrer oldı rihlet

Çağırdı yanına ol Mâhı halvet (252)

Bu noktadan sonra Mâh önemli bir karakter olarak ön plana çıkar ve neredeyse hikâye boyunca olaylar onun etrafında şekillenir. Zindana atılan Mâh'ın Mihr'e kavuşmak için dahi olsa dinini terk etmemesiyle olayların düğümü çözülür. Mâh, Mihr’in yardımıyla zindandan çıkar, kavuşur ve kaçarlar.

Bihamdillâh geçüp bu savm-ı hicrân

Müyesser oldı 'iyd-i vaslun ey cân (748)

Bu âyîn üzre ol iki yüzi gün

İderdi subh irince zevk her gün

Velî her şeb ol iki mâh-tal'at

Firâr içün ararlar idi firsat (765-766)

Mâh’ın ölümüyle hikâye neticelenir. Mihr'in Mâh öldükten sonra karalar giyip yas tutması, ölmek için dua etmesi ve duasının kabul olması, Mihr’i anlatının duygudaşlık doğurduğu kişisi hâline getirir.

Çü Mehden Mihr-i ferruh oldı mehcûr

Giyüp kara nitekim sâm-ı deycûr (1115)

Şu âş̧ık ki ola ma şûkk anun fevt

Diri olmakdan ana yegdürür mevt (1118) 
Hezârân âferîn ol dilsitâna

Virüp cân irdi vasl-ı câvidâna (1122)

Eserde başkarakterlerden biri olarak hikâyeye sonradan katılan Mâh'ın ilk ve son olayda merkez kişi olması, Mihr ü Mâh mesnevisinin A. Olrik'in Epik Yasaları'ndan “ilk ve son durumun önemi kuralı”yla uyumlu olduğunu göstermektedir.

\section{Anlatımda tek çizgililik kuralı:}

"Çağdaş edebiyat -bu terimi en geniş anlamıla kullanıyorum- çeşitli entrika çizgilerini birbirine dolayıp karıștırmaktan hoșlanıyor. Buna karşlık halk anlatısı bir olay çizgisini başkasıyla karıştırmaz; halk anlatıları her zaman tek çizgilidir. Eksik kalan ayrıntıları tamamlamak için geriye dönüş yapmaz. Ĕger daha önceki olaylar hakkında bilgi vermek gerekiyorsa, bu bir konuşmanın içinde verilir" (Olrik 1994b: 4).

Eserde anlatılan olaylar bir sebep-sonuç ilişkisi dahilinde kronolojik sıra ile verilir. Eksik kalan ayrıntıları tamamlayıcı ya da anımsatıcı geri dönüşler yoktur. Her olay kendi çizgisinde başkasıyla karıştırılmadan anlatılır.

Dağda çaresiz kalan Mâh, Allah'a münacat eder. Mâh'ın duası ile oğlunun hâlinden haberdar edilen Hilâl Şâh, hemen oğlunu kurtarmak için harekete geçer. Mâh başından geçenleri anlatırken dahi geriye dönüş yapılmaz. Olayla ilgili bilgi konuşma içerisinde verilir. Hemen hemen her olayda da bir sebep-sonuç ilişkisi vardır. Mâh’n başına gelen olaylar babasının kendisine verdiği yalnız ava çıkmaması öğüdünü göz ardı ettiği içindir. Pervîn, kızı Mihr’i Mâh’ın İslamiyet’i terk etmesine karşılık kendisine verecektir. Mâh’ın zindandayken sabredip dininden dönmemesi de zindandan kurtulmasıyla sonuçlanır.

Genel itibariyle ana hikâyenin kendi olay çizgisinde yan olaylarla beslenen bir şekilde ilerlemesi söz konusudur ki; mesnevi bu yönüyle Olrik’in "anlatımda tek çizgilik kuralı”yla uyumludur.

\section{Büyük tablo sahneleri kuralı:}

"Sage her zaman Büyük Tablo Sahneleri ile doruğuna erișir. Bu sahnelerde Sage kahramanları yan yana gelirler: kahraman ve atı, kahraman ve canavar, ... Bu görkemli durumlar çoğu zaman gerçeğe değil hayale dayanır. ... Büyük Tablo Sahnelerinin bir geçicilik duygusu değil, bir çeşit zaman içinde süreklilik niteliği taşıdığı fark ediliyor” (Olrik 1994b: 4-5).

Hikâyenin geneline bakıldığında "büyük tablo sahnesi" kabul edilebilecek birden fazla sahne olduğu görülür. Mâh’in esir düştüğü Pervîn’in sarayı kendisi için bir nevi dar mekân iken, orada Mihr ile birbirlerini ilk gördükleri sahne gayet etkileyicidir. Mâh’ın rüyasında aşina olduğu Mihr’i karşısında görmesi aşinalı̆̆ı tanışıklığa dönüştürürken, Mâh’ı ilk defa gören Mihr’in de ona âşık olması olayın etkileyiciliğini daha da artırmıştır.

Göricek Mâhı böyle Mihr-i Pervîn

O dahi ana âşsk oldı ol hîn

Velî Mihrün iderken hüsnini seyr

Önine düşdi Mâhun gördiği seyr (558-559)

Mihr'in, babası Pervîn'in planına uymayıp Mâh’ı dininden çıarmak yerine kendisinin İslamiyet’i seçmesi ve birlikte kaçışlarının anlatıldığı sahneler okuyucuda derin etki uyandırır. Pervîn ve 
askerlerinin Mihr ile Mâh’ı kaçarken yakalamaları üzerine, Mihr'in Mâh'ı yalnız bırakmamak adına onunla birlikte babasına karşı savaşmak istemesi de hikâyede önemli yer tutar.

Çü Meh gördi kim irdi ceyş-i Pervîn

Dönüp Mihre didi ey Zühre-âyîn

Bu tag üzre karâr ile çıkup sen

İnüp bunlar ile cenk ideyin ben

Çü Mihr andan işitdi bu hitâbı

Didi ey çarh-ı hüsnün mâh-tâbı

Bana bir lahza sensiz olmadan sag

Ölüp yegdür kim olam tưme-i zâg (780-784)

Hilâl Şâh ile Pervîn'in askerleri arasında geçen savaş sahneleri de önemlidir. Mâh'ın vefatından sonra acısına dayanamayı Mihr’in de canını alması için Allah'a dua etmesi ve ölmesi hikâyenin etkileyici bir sahne ile son bulmasını sağlamıştır.

Şu âşık ki ola ma'şûk anun fevt

Diri olmakdan ana yegdürür mevt (1118)

Hezârân âferîn ol dilsitâna

Virüp cân irdi vasl-ı câvidâna (1122)

\section{Tek entrika kuralı:}

"Sage için önemli bir ölçüdür. Bu en iyi gerçek Sage ile edebî eser karşlaştırılınca görülür. Entrika yapısında olayların ve belirsiz hareketlerin varlığı ürünün elden geçirildiğinin en belirgin işaretidir" (Olrik 1994b: 5).

Hikâyedeki tek entrika Mâh’nn İslamiyeti terk etmesi üzerine kuruldur. Bu entrika üzerinden kurgulanan üç olay hikâyede şöyle cereyan eder: Pervîn Şâh bir eğlence meclisi düzenleyerek kızı Mihr'i süsler ve Mâh’ın karşısına çıkarır. Mihr'in güzelliği ile kendisinden geçen Mâh’a içecek olarak şarap sunulacak, Mâh'ın da fark edemeden şarabı içip dinini terk etmesi sağlanacaktır. İlk olayda başarılı olamayan Pervîn Şâh, Mâh'ı kızı Mihr'den ayırmak için sebepsiz yere zindana atar. Asıl entrika ikinci olayda başlar. Bu olayda, Pervîn tarafından zindana atılan Mâh’a vezirinin önerisiyle bir nevi tuzak kurulur.

Didi irmek dilersen vasl-ı Mihre

Var ey Meh sabr it âlâm-ı sipihre

Bu gülzârun dikensiz verdi olmaz

Bulınmaz bir hezârı derdi olmaz

Bu gülşenden koparmak istiyen gül

İder hârı belâsına tahammül (505-507) 
Pervîn Şâh kızı Mihr'den zindana giderek Mâh’ı kandırmasını, ona dinini terk etmesi karşllığında zindandan çıkabileceğini ve evlenebileceklerini söylemesini ister. Mihr, babasına bu planını uygulayacağını söyleyip zindana gider. Ancak orada babasının planına sadık kalmayarak Mâh'a kendisi için kurgulanan oyunu anlatır.

Çün itdi terk hâr-ı küfri ol gül

Açup gonce lebin ol dem çü bülbül

Didi ey burc-1 hüsn üzre bugün Mâh

Beni saldı sana Pervîn-i bed-hrâh

Ki zindândan seni itlâk idem ben

Alup kasrima izzetle gidem ben

Garaz bundan bu kim çün Şeyh Sanân

Sana terk itdürem ben dîn ü îmân (709-712)

Mâh ile Mihr'in arasında gerçekleşen bu diyalogun ardından Pervin'in planının tam aksine Mihr Müslüman olur. Onun samimiyetine ikna olan Mâh da Mihr'e olan muhabbetini izhar eder. Akabinde kendi aralarında kurguladıkları yeni bir oyunla Pervîn Şâh'ın planına uymuş gibi zindandan çıkarlar. Bu noktada Mihr'in babasının entrikasına entrika kurması, dahası Mâh için İslamiyet’i seçmesi okuyucuyu şaşırtır.

Çün irdi cennet-i kasrına mesrûr

Geyürüp tâze hulle didi ol hûr

Bu ruhsat içre ger Hak vire firsat

Senünle ben kllam Çîne 'azîmet

Cihân dârina sensiz olmadan beg

Kapunda câriye olmak bana yeg (736-738)

Anlatıda sahnelenen üç olayın da hikâye boyunca tek bir entrika etrafında kurgulanması, Mihr ü Mâh mesnevisinin A. Olrik'in Epik Yasaları'ndan biri olan “tek enrika kuralı"yla uyumlu olduğu kanaatini doğurmaktadır.

\section{Dikkati baş kahraman üzerine toplama kuralı:}

"Halk anlatı geleneğinin en büyük kuralı Dikkati Baş Kahraman Üzerine Toplama'dır. Tarihsel olaylar Sage'de anlatılıyorsa, dikkat kahraman üzerinde toplanır. Sage'de iki kahraman belirdiği zaman halk anlatısının nasıl geliştiğini görmek çok ilgi çekicidir. Bir tanesi her zaman başkahramandır. Sage onun hikâyesiyle başlar ve bütün dış görüntüsüyle o, en önemli karakterdir” (Olrik 1994b: 5).

Zarîfi’nin mesnevisinde Mihr ile Mâh'ı iki başkarakter olarak merkezine alan bir hikâye anlatılmaktadır. Olaylar onların etrafında döner, okuyucunun tüm dikkati hikâye boyunca bu iki kahraman üzerine yoğunlaşır. Anlatının başında Hilâl Şâh’ın oğlu Mâh öncelenen karakter gibi görünür. Ancak ilerleyen 
bölümlerde esir düşen Mâh'ın Pervîn Şâh'ın sarayına götürülmesiyle Mihr de hikâyeye dahil olur. Sevdiği için babasının planını bozması, hatta babası Pervin’in askerlerine karşı Mâh ile birlikte savaşması, dikkatin odağını bir anda kendi üzerine çeker. Bu bakımdan hem Mâh hem de Mihr, zaman zaman odağı değişse de olaylarda her zaman dikkatlerin üzerlerinde toplandığı iki karakterdir. Hikâyenin odağında bu başkahramanların aşkı uğruna yaptıkları vardır. Okuyucunun bekletisi doğrultusunda karşılaştıkları tüm güçlükleri yan karakterlerin de yardımıyla ortadan kaldırarak kavuşurlar.

Hikâyenin geneli dikkate alındığında hemen hemen her bölümde dikkatlerin iki başkahraman üzerinde toplanmasından hareketle, mesnevinin epik yasalardan "dikkati baş kahramanın üzerinde toplama kuralı”yla da uyum arz ettiği görülür.

\section{Sonuc}

Tarihî-Coğrafi Fin Kuramı'nın önemli temsilcilerinden A. Olrik'in Halk Anlatılarmın Epik Yasaları, halk anlatılarının yapısal bakımdan çözümlenmesine katlı sağlamasıyla halkbilimi çalışmaları açısından önemli bir yere sahiptir. Olrik'e toplumsal toplumsal hafizada saklanan kültürel veriler sagelerde bilinçli veya bilinçsiz bir şekilde korunur. Farklı araştırmacılar tarafından yapılan çalışmalarda destan, tiyatro, karagöz oyunu ve roman gibi farklı anlatı türleri Olrik’in epik kuralları ışığında incelenmiş ve büyük oranda bu söz konusu yasaların varlığına tesadüf edilmiştir.

İncelenen farklı çalışmalardan hareketle Axel Olrik'in Epik Yasaları'nın varlığı, muhteva yönüyle halk hikâyeleriyle büyük benzerlik gösteren bir Klasik edebiyat ürünü olan Çorlulu Zarîfi’nin Mihr ü Mâh mesnevisinde incelenmiştir. İnceleme sonucunda A. Olrik'in Epik Yasaları'ndan Giriş ve Bitiş Kural, Yineleme Kurah, Üçler Kurah, Bir Sahnede İki Kurah, Zıtlkk Kural, İlkve Son Durumun Önemi Kural, Anlatımda Tek Çizgilik Kurah, Büyük Tablo Sahneleri Kurah, Tek Entrika Kurah ve Dikkati Baş Kahramanin Üzerinde Toplama Kuralı'nın Mihr ü Mâh mesnevinde yer aldığı görülmüştür. Bu bağlamda sözlü kültür ile Klasik edebiyattaki mesnevi geleneğinin birbirinden kopuk olmadığı kanısına varılmıştır. Epik kuralların Klasik edebiyatın mesnevi türüne uyarlanması noktasında yapılacak başka çalışmalar, bu kanının doğrulanmasına katkı sağlayacaktır.

\section{Kaynakça}

Akyüz, Çiğdem (2012), "Haldun Taner’in 'Keşanlı Ali Destanı' ve Axel Olrik’in Epik Yasaları”, Adryaman Üniversitesi Sosyal Bilimler Enstitüsü Dergisi, 8, 1-11.

Alptekin, Ali Berat (2005), Halk Hikâyelerinin Motif Yapısı, Akçă̆ Yayınları, Ankara.

Bars, Mehmet Emin (2014), “A. Olrik’in Epik Yasaları Işı̆̆ında Ferhat İle Şirin Hikâyesi”, Uluslararası Türkçe Edebiyat Kültür Eğitim Dergisi, 3/1, 306-324.

Boratav, Pertve Naili (1999), 100 Soruda Türk Halk Edebiyatı, Gerçek Yayıncılık, İstanbul

Çiftçi, Ferhat (2013), “Axel Olrik’in Epik Yasaları Işı̆̆ında Oğuz Kağan Destanı'na Bir Bakış”. Turkish Studies, 8/4, 515-524.

Çobanoğlu, Özkul (2002). Halkbilimi Kuramları ve Araştırma Yöntemleri Tarihine Giriş, Akçă̆ Yayınları, Ankara.

Ekici, Metin (2006), “Araştırma Yöntemleri”, Türk Halk Edebiyatı El Kitabı (ed. M. Öcal Oğuz), Grafiker Yayınları, Ankara.

Erdoğan, Mehtap (2010), "Yazma Kültürüne Ait Bir Metne Epik Yasaların Uygulanması Denemesi”, Turkish Studies, Volume 5/3 Summer: 1198-1217. 
Gülmen, Nuriye (2008), “Axel Olric'in Epik Yasaları Işı̆ğında 'Salur Kazanun Evi Yagmalandugı Boyu Beyan Eder' İsimli Hikâyenin Okunması”, Millî Folklor, 79, 14-20.

Kavruk, Hasan, PALA, İskender (1998), "Hikâye", İslam Ansiklopedisi, C.2, Türkiye Diyanet Vakfi, İstanbul, s. 490-493.

Olrik, Axel (1994a), “Halk Anlatılarının Epik Kuralları”, Millî Folklor, 23, 2-5.

Olrik, Axel (1994b), "Halk Anlatılarının Epik Kuralları II”, Millî Folklor, 24, 4-6.

Özcan, Tarık (1996), "Oğuz Kağan Destanı’nın Halk Anlatılarının Epik Kuralları Bakımından İncelenmesi”, Millî Folklor, 31-32, 95-97.

Tuncel, Uğur (2013), “Axel Olrik’in Halk Anlatılarının Epik Yasaları Bağlamında ‘Ağalık' Adlı Karagöz Oyunu Çözümlenmesi”, İstanbul Üniversitesi Türk Dili ve Edebiyatı Dergisi, XLVIII, 203-240.

Turhan, Vedat Nuri (1995), Zarîfî ve Mihr ü Mâh Mesvisi'nin Tenkidli Metni ile İncelemesi, Yayınlanmamış Yüksek Lisans Tezi, Atatürk Üniversitesi, Erzurum.

Türkmen, Fikret (1998), ), "Hikâye”, İslam Ansiklopedisi, C.2, Türkiye Diyanet Vakfı, İstanbul, s. 490493.

Ünver, İsmail (1986). “Mesnevi”, Türk Dili, Türk Şïri Özel Sayısı II (Divan Şiiri), 415-416-417, Türk Dil Kurumu Yayınları, Ankara, s. 430-563.

Yllmaz, Mehmet (1999), Manas Destanı'nın Epik Kurallara Göre İncelenmesi (Sagınbay Orazbakov Varyantı, C.1), Yayımlanmamış Doktora Tezi, Atatürk Üniversitesi, Erzurum.

Yllmaz, Mehmet (2009), "Hamdi’nin Yûsuf u Züleyhâ Mesnevisi'nin Epik Karakterinin Değerlendirilmesi Üzerine Bazı Tespitler”, Turkish Studies, 4/8, 2444-2461.

Zariç, Mahfuz (2007), "Kirdeci Ali Kesikbaș Destanı’nın Metin Merkezli Temel Halkbilimi Kuramları Açısından İncelenmesi”, Erciyes Üniversitesi Sosyal Bilimler Enstitüsü Dergisi, 22: 199-216. 